\title{
Studies on effective PCR screening strategies for white spot syndrome virus (WSSV) detection in Penaeus monodon brooders
}

\author{
Hui-Chen Hsu' ${ }^{1}$, Chu-Fang Lo ${ }^{1}$, Shan-Ching Lin ${ }^{1}$, Kuan-Fu Liu ${ }^{2}$, Shao-En Peng ${ }^{1}$, \\ Yun-Shiang Chang ${ }^{1}$, Li-Li Chen ${ }^{1}$, Wang-Jing Liu ${ }^{1}$, Guang-Hsiung Kou ${ }^{1, *}$ \\ 'Department of Zoology, National Taiwan University, Taipei, Taiwan, ROC \\ ${ }^{2}$ Tung-Kang Marine Laboratory, Taiwan Fisheries Research Institute, Tung-Kang, Ping-Tung, Taiwan, ROC
}

\begin{abstract}
We re-tested stored (frozen) DNA samples in 5 independent polymerase chain reaction (PCR) replicates and confirmed that equivocal test results from a previous study on white spot syndrome virus (WSSV) in brooders and their offspring arose because amounts of WSSV DNA in the test samples were near the sensitivity limits of the detection method. Since spawning stress may trigger WSSV replication, we also captured a fresh batch of 45 brooders for WSSV PCR testing before and after spawning. Replicates of their spawned egg batches were also WSSV PCR tested. For these 45 brooders, WSSV prevalence before spawning was $67 \%$ (15/45 1-step PCR positive, 15/45 2-step PCR positive and 15/45 2-step PCR negative). Only 27 (60\%) spawned successfully. Of the successful spawners, $56 \%$ were WSSV PCR positive before spawning and $74 \%$ after. Brooders (15) that were heavily infected (i.e. 1 -step PCR positive) when captured mostly died within 1 to $4 \mathrm{~d}$, but $3(20 \%)$ did manage to spawn. All their egg batch sub-samples were 1-step PCR positive and many failed to hatch. The remaining 30 shrimp were divided into a lightly infected group (21) and a 2-step PCR negative group (9) based on replicate PCR tests. The spawning rates for these 2 groups were high ( 81 and $78 \%$, respectively). None of the negative spawners (7) became WSSV positive after spawning and none gave egg samples positive for WSSV. In the lightly infected group (21), 6 brooders were 2-step WSSV PCR negative and 15 were 2-step WSSV PCR positive upon capture. However, all of them were WSSV PCR positive in replicate tests and after spawning or death. Four died without spawning. The remaining 17 spawned but only 2 gave egg samples PCR negative for WSSV. The other 15 gave PCR positive egg samples, but they could be divided into 2 spawner groups: those (7) that became heavily infected (i.e. 1-step PCR positive) after spawning and those (8) that remained lightly infected (i.e. became or remained 2-step PCR positive only). Of the brooders that became heavily infected after spawning, almost all egg sample replicates $(91 \%$ ) tested 2 -step PCR positive. One brooder even gave heavily infected (i.e. 1-step PCR positive) egg samples. For the brooders that remained lightly infected after spawning, only $27 \%$ of the egg sample replicates were 2-step PCR positive. Based on these results, we recommend that to avoid false negatives in WSSV PCR brooder tests screening tests should be delayed until after spawning. We also recommend, with our PCR detection system, discarding all egg batches from brooders that are 1-step PCR positive after spawning. On the other hand, it may be possible with appropriate monitoring to use eggs from 2-step PCR positive brooders for production of WSSV-free or lightly infected postlarvae. These may be used to stock shrimp ponds under low-stress rearing conditions.
\end{abstract}

KEY WORDS: WSSV $\cdot$ Carrier $\cdot$ Brooder $\cdot$ Penaeus monodon

\section{INTRODUCTION}

Outbreaks of white spot syndrome virus (WSSV) have led to serious mortalities among populations of cultured shrimp in several Asian countries (Inouye et al. 1994, Momoyama et al. 1994, Nakano et al. 1994,

\footnotetext{
•Corresponding author, E-mail: ghkou@ccms.ntu.edu.tw
}

Takahashi et al. 1994, Cai et al. 1995, Chou et al. 1995, Wang et al. 1995, Wongteerasupaya et al. 1995, Lo et al. 1996a, Peng et al. 1998). The principal clinical sign of this disease is the presence of white spots in the exoskeleton and epidermis of diseased shrimp, with the spots varying in size from barely visible to $3 \mathrm{~mm}$ in diameter. Histopathological studies have demonstrated that the causative agent, WSSV, most frequently attacks the cuticular epidermis, where its pres- 
ence is evident in degenerated cells with hypertrophied nuclei (Wang et al. 1995). The effects of WSSV pathogenesis are often acute, with mortality typically reaching 100\% within 2 to $7 \mathrm{~d}$ (Momoyama et al. 1994, Chou et al. 1995, Wang et al. 1995). Recently, WSSV has also been shown to cause disease, high mortality and/or latent infections not only in shrimp, but also in crabs and other arthropods (Lo et al. 1996b, 1997, Lo \& Kou 1998).

WSSV targets various tissues of captured Penaeus monodon brooders, including the reproductive organs. In the ovary, Lo et al. (1997) found WSSV particles in follicle cells, oogonia, developing oocytes and connective tissue. Investigation of WSSV infection by 2 -step polymerase chain reaction (PCR) revealed that some positive brooders produced larval batches that gave both 2-step WSSV PCR positive and negative test results with different sub-samples (Lo et al. 1997). A more recent study of a single WSSV-carrier brooder revealed that $10 \%$ of its 13 mo old, outwardly healthy, adult offspring had tiny white spots on their carapace and exhibited WSSV-infected cells in the stomach integument, gills and other organs by in situ DNA hybridization (Tsai et al. 1999). These results indicate that the quantity of WSSV DNA in tested brooders may sometimes be near the limits of detection methods. In this paper, we further investigated WSSV infections in brooders, in an attempt to find a method for more effective screening. As part of this process, we reexamined stored samples of DNA from 2-step WSSV positive brooders described in a previous publication (Lo et al. 1997). We also applied a more rigorous screening procedure to a batch of 1998 brooders and their offspring.

\section{MATERIALS AND METHODS}

Re-examination of stored DNA samples from 1995 brooders. The Penaeus monodon DNA samples retested here were derived from an earlier study of captured brooders (Lo et al. 1997) and had been stored at $-20^{\circ} \mathrm{C}$. Specimens from the earlier study were selected only if they had previously tested negative for WSSV or positive by 2-step PCR. Specimens that were 1-step PCR positive were not included. Sub-fractions of each selected sample were checked in 4 more independent $\mathrm{PCR}$ reactions.

Detection of WSSV in newly captured brooders before and after spawning. Penaeus monodon brooders were captured from their natural environment in the coastal waters around southern Taiwan, either in April or between August and November 1998. They were immediately transported to the Tung Kang Marine Laboratory of the Taiwan Fisheries Research Institute in Ping Tung Prefecture, and upon arrival, a pleopod was removed from each shrimp. To minimize handling stress and collateral damage during pleopod removal, each brooder was wrapped in a wet towel so that only the appendage to be removed remained exposed. The pleopod was then excised with a red-hot pair of forceps in a manner similar to that for eyestalk ablation. Some of the DNA extracted from the pleopod was then subjected immediately to 2-step WSSV diagnostic PCR (Lo et al. 1996a) and the remainder was stored at $-20^{\circ} \mathrm{C}$ for later use. All the brooders used were mature and ready to spawn, so eyestalk ablation was not used to induce spawning. Subsequently, the brooders were maintained in reproduction facilities (1 brooder in each 5001 fiber reinforced plastic (FRP) tank containing $450 \mathrm{l}$ aerated, filtered $33 \%$ seawater at $30 \pm 1{ }^{\circ} \mathrm{C}$, $\mathrm{pH}$ 8.3) for spawning. A few hours after spawning, the brooders were transferred to new tanks ( 1 brooder in each $67 \mathrm{l}$ tank containing $50 \mathrm{l}$ aerated, filtered 33\% seawater at $30 \pm 1^{\circ} \mathrm{C}, \mathrm{pH}$ 8.3) to prevent horizontal transmission of WSSV. At the time of transfer, another pleopod was excised and subjected to DNA extraction. Most of the extracted DNA was stored at $-20^{\circ} \mathrm{C}$, and only a portion was used immediately for WSSV diagnostic PCR to determine the prevalence of WSSV in brooders after spawning. This meant that the first 2 PCR tests for each brooder were made only hours apart, and this contrasts with our earlier study (Lo et al. 1997), where several days elapsed between the preand post-spawning tests. Brooders that failed to spawn were not tested a second time, except after death. Stored DNA samples extracted pre- and post-spawning (or post-death) were subsequently sub-sampled and subjected to 5 additional replications of 2-step WSSV diagnostic PCR. Samples of eggs from all the brooders that spawned were also extracted and tested for the presence of WSSV using 2-step diagnostic PCR.

WSSV diagnostic PCR. A DNA extraction kit (Farming IntelliGene Tech. Corp., Taipei, Taiwan) was used to isolate the template DNA for diagnostic PCR. This kit is based on a simplified extraction protocol (Lo et al 1996a, 1998). Briefly, an excised pleopod was placed in an Eppendorf tube containing $0.6 \mathrm{ml}$ of a premixed 'DTAB' solution provided with the extraction kit, crushed with a disposable bamboo stick, and then incubated for $5 \mathrm{~min}$ at $75^{\circ} \mathrm{C}$. This was followed by extraction with $0.5 \mathrm{ml}$ of chloroform once, brief vortexing and centrifugation at $12000 \times g$ for $3 \mathrm{~min}$. The upper aqueous phase was transferred to a new Eppendorf tube with $0.1 \mathrm{ml}$ 'CTAB' (also pre-mixed and provided with the kit) and $0.9 \mathrm{ml}$ double-distilled $\mathrm{H}_{2} \mathrm{O}$ for $5 \mathrm{~min}$ at $75^{\circ} \mathrm{C}$ before being allowed to cool down to room temperature. After centrifugation at $12000 \times \mathrm{g}$ for $10 \mathrm{~min}$, the pellet was collected and resuspended in $150 \mu \mathrm{l}$ of the 'Dissolving Solution' provided with the kit 
for $5 \mathrm{~min}$ at $75^{\circ} \mathrm{C}$. After further centrifugation at 12000 $\times g$ for 5 min, the supernatant was transferred to a new Eppendorf tube with $300 \mu \mathrm{l} 95 \%$ ethanol, mixed well and centrifuged again at $12000 \times g$ for $5 \mathrm{~min}$. The pellet was then washed with $200 \mu \mathrm{l} 70 \%$ ethanol and resuspended in double-distilled $\mathrm{H}_{2} \mathrm{O}$ at $65^{\circ} \mathrm{C}$ for $15 \mathrm{~min}$ before the DNA concentration was measured by ultraviolet absorbance at $260 \mathrm{~nm}$ using an RNA/DNA calculator (GeneQuantII, Pharmacia Biotech, Sweden). WSSV diagnostic PCR was then performed as described previously (Lo et al. 1996a,b).

\section{RESULTS}

\section{Re-examination of stored DNA samples from 1995 brooders}

In the original replication of 2-step WSSV diagnostic PCR (Lo et al. 1997), 10 of the 24 tested DNA samples $(41.67 \%)$ gave negative results (Table 1$)$. However, after 4 more replications with the same templates, only 4 samples $(16.67 \%$ ) were consistently 2 -step WSSV

Table 1. Penaeus monodon. Five replications of WSSV detection in brooders using 2-step WSSV diagnostic PCR No specimens were originally 1-step PCR positive. Designation numbers used here consist of the year and month of capture followed by the specimen number originally used by Lo et al. (1997). Data for the first replication are taken from Lo et al. (1997)

\begin{tabular}{|c|c|c|c|c|c|c|c|}
\hline \multicolumn{2}{|c|}{ Shrimp } & \multicolumn{5}{|c|}{ 2-step nested PCR } & \multirow[b]{2}{*}{ Total } \\
\hline No & Designation & 1 & 2 & 3 & 4 & 5 & \\
\hline 1 & $9507 \mathrm{~S} 01$ & + & - & + & + & + & $4 / 5$ \\
\hline 2 & $9507 \mathrm{~S} 02$ & + & + & - & + & + & $4 / 5$ \\
\hline 3 & $9507 \mathrm{~S} 03$ & + & + & - & + & + & $4 / 5$ \\
\hline 4 & $9507 \mathrm{~S} 04$ & - & - & + & + & - & $2 / 5$ \\
\hline 5 & $9507 \mathrm{~S} 05$ & + & - & + & - & - & $2 / 5$ \\
\hline 6 & $9507 \mathrm{~S} 06$ & - & - & - & - & - & $0 / 5$ \\
\hline 7 & 9507514 & + & + & + & + & + & $5 / 5$ \\
\hline 8 & $9507 \mathrm{~S} 15$ & - & + & - & + & + & $3 / 5$ \\
\hline 9 & $9507 \$ 16$ & + & - & - & + & + & $3 / 5$ \\
\hline 10 & $9507 \mathrm{~S} 17$ & + & + & - & - & - & $2 / 5$ \\
\hline 11 & $9507 \mathrm{~S} 19$ & - & - & - & - & - & $0 / 5$ \\
\hline 12 & $9507 \$ 20$ & + & + & - & - & + & $3 / 5$ \\
\hline 13 & $9507 \mathrm{~S} 21$ & - & - & + & + & - & $2 / 5$ \\
\hline 14 & $9507 \mathrm{~S} 22$ & + & - & + & - & - & $2 / 5$ \\
\hline 15 & $9507 \mathrm{~S} 23$ & + & + & - & + & - & $3 / 5$ \\
\hline 16 & $9507 \mathrm{~S} 24$ & - & - & + & + & + & $3 / 5$ \\
\hline 17 & $9507 \mathrm{~S} 25$ & - & + & - & + & + & $3 / 5$ \\
\hline 18 & $9507 \mathrm{~S} 26$ & - & - & - & - & - & $0 / 5$ \\
\hline 19 & $9507 \mathrm{~S} 27$ & - & - & - & - & + & $1 / 5$ \\
\hline 20 & $9507 \mathrm{~S} 28$ & + & + & - & + & - & $3 / 5$ \\
\hline 21 & 9507 S29 & - & - & - & - & - & $0 / 5$ \\
\hline 22 & $9507 \mathrm{~S} 30$ & + & + & + & + & + & $5 / 5$ \\
\hline 23 & $9508 \mathrm{~S} 55$ & + & - & + & - & + & $3 / 5$ \\
\hline 24 & $9508 \mathrm{~S} 56$ & + & - & + & - & - & $2 / 5$ \\
\hline
\end{tabular}

PCR negative and the other 20 gave a positive result at least once. This suggested that these 20 samples contained the WSSV template, although the number of positive PCR results obtained in each round of replication only ranged from 42 to $58 \%$ (i.e. 10 to 14 out of 24)

\section{Detection of WSSV in brooders before and after spawning}

For the 45 newly captured brooders (Table 2), the immediate tests for WSSV after capture gave 15 (33\%) 1 -step PCR positive, 15 (33\%) 2-step PCR positive and $15(33 \%) 2$-step PCR negative. The 15 brooders 1 -step WSSV positive upon capture were classified as heavily infected'. Three of these spawned but almost died afterwards. The other 12 failed to spawn and eventually died. The 15 brooders 2 -step WSSV positive upon capture were classified as 'lightly infected'. Of these, 3 failed to spawn and died, testing 1 -step positive after death. The 15 brooders 2 -step negative upon capture fell into 2 groups, those that remained negative throughout testing and those that gave positive WSSV results after spawning or death. The latter were classified as 'lightly infected', like the brooders that were 2step WSSV positive upon capture. Taken together, the 'lightly infected' brooders numbered 21. Four of these (1 being 2-step WSSV negative upon capture) did not spawn and died, testing 1-step WSSV positive after death. The 17 remaining 'lightly infected' brooders spawned. After spawning, 4 of the initially 2-step negative brooders became 2-step positive, and 1 became 1 -step positive, while 6 of the 2 -step positive brooders became 1 -step positive and 6 remained 2-step positive. Of the 9 brooders that were 2-step negative, only 7 spawned and they gave WSSV negative tests after spawning. Only brooders that were 2-step negative after spawning were classified as truly 2-step WSSV negative.

Five additional 2-step PCR replicate tests (Table 3) were carried out using the stored parallel DNA extracts prepared upon shrimp capture and spawning. All 21 brooders assigned to the 'lightly infected' groups in Table 2 gave consistently positive results in 2-step PCR tests after spawning. However, results for their tests before spawning were somewhat variable. Assuming that the positive PCR result after spawning or death indicated a true infection, successful detection rates before spawning only ranged from 62 to $76 \%$ for each round of replication (Table 3). The 9 brooders classified as 2-step PCR negative in Table 2 were consistently 2-step WSSV PCR negative in all replicate tests, before and after spawning or without spawning. Indeed, the 2 brooders that did not spawn were still negative 1 mo after capture. 
Table 2. Penaeus monodon. Detection of WSSV by 2-step WSSV diagnostic PCR in 45 brooders before and after spawning and eggs of these brooders. Designation numbers used here consist of the year and month of capture followed by the specimen number. Brooders were sacrificed after spawning. Brooders that failed to spawn were not tested a second time or were tested only after death. Values for WSSV diagnostic PCR of eggs represent the number of DNA samples positive in the first or second step PCR and the number of DNA samples examined. nd: not done

\begin{tabular}{|c|c|c|c|c|c|c|c|c|c|c|c|}
\hline \multirow{3}{*}{\multicolumn{2}{|c|}{$\begin{array}{l}\text { Shrimp } \\
\text { No. Designation }\end{array}$}} & \multirow{4}{*}{$\begin{array}{c}\text { Spawning } \\
\text { (Yes/No) } \\
\text { Yes }\end{array}$} & \multirow{4}{*}{$\begin{array}{l}\text { Group } \\
\text { Heavily }\end{array}$} & \multicolumn{6}{|c|}{ WSSV diagnostic PCR of brooders } & \multirow{2}{*}{\multicolumn{2}{|c|}{$\begin{array}{c}\text { WSSV diagnostic } \\
\text { PCR of eggs }\end{array}$}} \\
\hline & & & & \multicolumn{2}{|c|}{ Before spawning } & \multicolumn{2}{|c|}{ After spawning } & \multicolumn{2}{|c|}{ After death } & & \\
\hline & & & & $1 \mathrm{st}$ & 2nd & $1 \mathrm{st}$ & 2nd & $1 \mathrm{st}$ & $2 n d$ & \multicolumn{2}{|c|}{1 st $\quad 2$ nd } \\
\hline 1 & $9804 \mathrm{~S} 01$ & & & + & + & + & + & & & $2 / 2$ & $2 / 2$ \\
\hline 2 & $9804 \mathrm{~S} 02$ & Yes & infected & + & + & + & + & & & $2 / 2$ & $2 / 2$ \\
\hline 3 & 9809527 & Yes & & + & + & + & + & & & $10 / 10$ & $10 / 10$ \\
\hline 4 & $9809 S 43$ & No & & + & + & & & + & + & & \\
\hline 5 & $9809 \$ 45$ & No & & + & + & & & + & + & & \\
\hline 6 & 9809547 & No & & + & + & & & + & + & & \\
\hline 7 & $9809 \mathrm{~S} 51$ & No & & + & + & & & + & + & & \\
\hline 8 & $9809 \mathrm{~S} 52$ & No & & + & + & & & + & + & & \\
\hline 9 & $9809 S 53$ & No & & + & + & & & + & + & & \\
\hline 10 & 9809554 & No & & + & + & & & + & + & & \\
\hline 11 & $9809 \mathrm{~S} 55$ & No & & + & + & & & + & + & & \\
\hline 12 & $9809 \$ 56$ & No & & + & + & & & + & + & & \\
\hline 13 & 9809557 & No & & + & + & & & + & + & & \\
\hline 14 & $9809 \$ 59$ & No & & + & + & & & + & + & & \\
\hline 15 & $9809 \mathrm{~S} 60$ & No & & + & + & & & + & + & & \\
\hline 16 & $9804 \mathrm{~S} 03$ & Yes & Lightly & - & + & + & + & & & $0 / 2$ & $2 / 2$ \\
\hline 17 & $9804 \mathrm{~S} 04$ & Yes & infected & - & + & + & + & & & $0 / 2$ & $2 / 2$ \\
\hline 18 & $9809 \$ 26$ & Yes & & - & + & + & + & & & $0 / 10$ & $10 / 10$ \\
\hline 19 & $9809 \$ 29$ & Yes & & - & + & + & + & & & $0 / 10$ & $10 / 10$ \\
\hline 20 & $9810 S 71$ & Yes & & - & + & + & + & & & $0 / 6$ & $6 / 6$ \\
\hline 21 & $9811 \mathrm{~S} 78$ & Yes & & - & + & + & + & & & $4 / 10$ & $1.0 / 10$ \\
\hline 22 & $9809 \$ 28$ & Yes & & - & + & - & + & & & $0 / 10$ & $4 / 10$ \\
\hline 23 & 9809531 & Yes & & - & + & - & + & & & $0 / 10$ & $4 / 10$ \\
\hline 24 & $9809 \$ 32$ & Yes & & - & + & - & + & & & $0 / 10$ & $3 / 10$ \\
\hline 25 & $9809 \$ 33$ & Yes & & - & + & - & + & & & $0 / 10$ & $3 / 10$ \\
\hline 26 & $9810 S 68$ & Yes & & - & + & - & + & & & $0 / 5$ & $0 / 5$ \\
\hline 27 & $9811 S 74$ & Yes & & - & + & - & + & & & $0 / 10$ & $1 / 1.0$ \\
\hline 28 & $9809 \$ 41$ & No & & - & + & & & + & + & & \\
\hline 29 & 9809550 & No & & - & + & & & + & + & & \\
\hline 30 & $9809 \$ 59$ & No & & - & + & & & + & + & & \\
\hline 31 & $9809 \$ 25$ & Yes & Lightly & - & - & - & + & & & $0 / 10$ & $4 / 1.0$ \\
\hline 32 & $9809 \mathrm{~S} 30$ & Yes & infected & - & - & - & + & & & $0 / 10$ & $3 / 10$ \\
\hline 33 & $9809 \$ 63$ & Yes & & - & - & -- & + & & & $0 / 5$ & $0 / 5$ \\
\hline 34 & 9810573 & Yes & & - & - & - & + & & & $0 / 5$ & $1 / 5$ \\
\hline 35 & $9810 \mathrm{~S} 65$ & Yes & & - & - & + & + & & & $0 / 5$ & $1 / 5$ \\
\hline 36 & $9809 S 24$ & No & & - & - & & & + & + & & \\
\hline 37 & $9809 S 34$ & Yes & 2-step & nd & nd & - & - & & & $0 / 6$ & $0 / 6$ \\
\hline 38 & $9809 \$ 35$ & Yes & PCR & nd & nd & - & - & & & $0 / 6$ & $0 / 6$ \\
\hline 39 & 9809538 & Yes & negative & nd & nd & - & - & & & $0 / 6$ & $0 / 6$ \\
\hline 40 & 9809561 & Yes & & - & - & - & - & & & $0 / 6$ & $0 / 6$ \\
\hline 41 & 9809562 & Yes & & - & - & - & - & & & $0 / 5$ & $0 / 5$ \\
\hline 42 & 9809564 & Yes & & - & - & - & - & & & $0 / 5$ & $0 / 5$ \\
\hline 43 & $9810 S 66$ & Yes & & - & - & - & - & & & $0 / 5$ & $0 / 5$ \\
\hline 44 & $9810 \$ 67$ & No & Not & - & - & & & & & & \\
\hline 45 & $9810 \$ 69$ & No & classified & - & - & & & & & & \\
\hline
\end{tabular}

\section{Prevalence of WSSV in brooders after spawning}

Excluding the brooders that were 1-step PCR positive upon capture and examining only the brooders in the 'lightly infected' groups, there was evidence that spawning could result in increased severity of WSSV infection. Excluding the 4 brooders that died, 11 (65\%) out of 17 brooders that spawned changed their WSSV infection status either from 2-step PCR negative to 2 step positive $(4 / 17=24 \%)$ or 1 -step positive $(1 / 17=$ $6 \%)$ or from 2 -step positive to 1 -step positive $(6 / 17=$ $35 \%)$ 
Table 3. Penaeus monodon. Five replications of WSSV detection in brooders before and after spawning using 2-step WSSV diagnostic PCR. Designation numbers consist of the year and month of capture followed by the specimen number. Parentheses indicate that the specimens failed to spawn and were tested only after death. ++: specimens tested positive in both the first and second steps of the 2-step diagnostic PCR. Specimens 9810 S67 and 9810 S69 failed to spawn but survived through to the end of the $14 \mathrm{~d}$ experimental period. Square brackets indicate that the stored DNA tested here was extracted 14 d after capture. nd: not done

\begin{tabular}{|c|c|c|c|c|c|c|c|c|c|c|c|c|c|c|c|}
\hline \multicolumn{2}{|c|}{ Shrimp } & \multicolumn{7}{|c|}{ Before spawning: 2-step PCR } & \multicolumn{7}{|c|}{ After spawning (after death): 2-step PCR } \\
\hline No. & Designation & 1 & 2 & 3 & 4 & 5 & Total & $\begin{array}{l}\text { WSSV- } \\
\text { infected }\end{array}$ & 1 & 2 & 3 & 4 & 5 & Total & $\begin{array}{l}\text { WSSV- } \\
\text { infected }\end{array}$ \\
\hline 16 & $9804 \mathrm{~S} 03$ & + & + & + & + & + & $5 / 5$ & Yes & ++ & ++ & ++ & ++ & ++ & $5 / 5$ & Yes \\
\hline 17 & $9804 \mathrm{~S} 04$ & + & + & + & + & + & $5 / 5$ & Yes & ++ & ++ & ++ & ++ & ++ & $5 / 5$ & Yes \\
\hline 18 & $9809 \mathrm{~S} 26$ & + & + & + & + & + & $5 / 5$ & Yes & ++ & ++ & ++ & ++ & ++ & $5 / 5$ & Yes \\
\hline 19 & $9809 \$ 29$ & + & + & + & + & + & $5 / 5$ & Yes & ++ & ++ & ++ & ++ & ++ & $5 / 5$ & Yes \\
\hline 20 & $9810 S 71$ & + & - & + & + & + & $4 / 5$ & Yes & $+t$ & ++ & ++ & ++ & ++ & $5 / 5$ & Yes \\
\hline 21 & $9811 \mathrm{~S} 78$ & + & - & - & - & - & $1 / 5$ & Yes & $+t$ & ++ & ++ & ++ & ++ & $5 / 5$ & Yes \\
\hline 22 & $9809 \$ 28$ & + & + & + & + & + & $5 / 5$ & Yes & + & + & + & + & + & $5 / 5$ & Yes \\
\hline 23 & $9809 \$ 31$ & + & - & + & + & + & $4 / 5$ & Yes & + & + & + & ++ & + & $5 / 5$ & Yes \\
\hline 24 & $9809 \mathrm{~S} 32$ & + & + & + & + & + & $5 / 5$ & Yes & + & + & + & + & + & $5 / 5$ & Yes \\
\hline 25 & 9809533 & + & + & + & + & + & $5 / 5$ & Yes & + & + & + & + & + & $5 / 5$ & Yes \\
\hline 26 & $9810 S 68$ & + & - & + & + & - & $3 / 5$ & Yes & + & + & ++ & + & + & $5 / 5$ & Yes \\
\hline 27 & $9811 \mathrm{~S} 74$ & + & - & - & - & - & $1 / 5$ & Yes & + & + & + & + & + & $5 / 5$ & Yes \\
\hline 28 & $9809 \$ 41$ & + & + & + & + & + & $5 / 5$ & Yes & $(++)$ & $(++)$ & $(++)$ & $(++)$ & $(++)$ & $5 / 5$ & Yes \\
\hline 29 & 9809550 & + & + & + & + & + & $5 / 5$ & Yes & $(++)$ & $(++)$ & $(++)$ & $(++)$ & $(++)$ & $5 / 5$ & Yes \\
\hline 30 & 9809559 & + & + & + & + & + & $5 / 5$ & Yes & $(++)$ & $(++)$ & $1++)$ & $(++)$ & $(++)$ & $5 / 5$ & Yes \\
\hline 31 & $9809 \$ 25$ & $\begin{array}{l}\top \\
-\end{array}$ & + & $\begin{array}{l}\mathrm{T} \\
-\end{array}$ & - & ${ }_{-}^{T}$ & $1 / 5$ & Yes & $\begin{array}{c}\text { ITT) } \\
+\end{array}$ & + & + & + & + & $5 / 5$ & Yes \\
\hline 32 & 9809530 & + & $\begin{array}{l}+ \\
+\end{array}$ & - & - & + & $3 / 5$ & Yes & + & + & + & + & + & $5 / 5$ & Yes \\
\hline 33 & $9809 \$ 63$ & $\begin{array}{l}\top \\
-\end{array}$ & - & - & - & + & $1 / 5$ & Yes & + & + & + & + & + & $5 / 5$ & Yes \\
\hline 34 & $9810 \mathrm{~S} 73$ & - & + & - & - & - & $1 / 5$ & Yes & + & + & + & + & + & $5 / 5$ & Yes \\
\hline 35 & 9810565 & - & - & - & - & + & $1 / 5$ & Yes & ++ & ++ & ++ & ++ & ++ & $5 / 5$ & Yes \\
\hline 36 & $9809 S 24$ & - & - & - & - & + & $1 / 5$ & Yes & $(++)$ & $(++)$ & $(++)$ & $(++)$ & $(++)$ & $5 / 5$ & Yes \\
\hline 37 & 9809534 & nd & nd & nd & nd & nd & nd & nd & - & - & - & (TT) & - & $0 / 5$ & No \\
\hline 38 & 9809535 & nd & nd & nd & nd & nd & nd & nd & - & - & - & - & - & $0 / 5$ & No \\
\hline 39 & $9809 \mathrm{~S} 38$ & nd & nd & nd & nd & nd & nd & nd & - & - & - & - & - & $0 / 5$ & No \\
\hline 40 & 9809561 & - & - & - & - & - & $0 / 5$ & No & - & - & - & - & 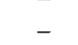 & $0 / 5$ & No \\
\hline 41 & 9809562 & - & - & - & - & - & $0 / 5$ & No & - & 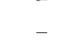 & - & - & - & $0 / 5$ & No \\
\hline $\begin{array}{l}41 \\
42\end{array}$ & 9809564 & - & - & - & - & - & $0 / 5$ & No & - & - & - & - & - & $0 / 5$ & No \\
\hline 43 & $9810 S 66$ & - & - & - & - & - & $0 / 5$ & No & - & - & - & - & - & $0 / 5$ & $\mathrm{No}$ \\
\hline 44 & 9810567 & - & - & - & - & - & $0 / 5$ & No & {$[-]$} & {$[-]$} & {$[-1$} & {$[-]$} & {$[-]$} & $0 / 5$ & No \\
\hline 45 & $9810 \$ 69$ & - & - & - & - & - & $0 / 5$ & No & {$[-]$} & {$[-]$} & $1-1$ & {$[-]$} & {$[-]$} & $0 / 5$ & No \\
\hline
\end{tabular}

\section{Negative impact of WSSV infection on spawning}

Of the 15 heavily infected brooders, only $3(20 \%)$ spawned successfully. Most of the others died within 1 to $4 \mathrm{~d}$ after capture without spawning. By contrast, more than $80 \%$ (17 out of 21 ) of the lightly infected brooders spawned successfully, as did $78 \%$ (7 out of 9) of the 2-step PCR negative brooders (Fig. 1).

\section{Egg infections}

All of the tested egg samples of the 3 heavily infected brooders that spawned successfully were 1-step PCR positive (Table 2, Fig. 2). Of the 17 lightly infected brooders that spawned, only 1 gave 1 -step PCR positive egg samples and only 2 gave 2 -step PCR negative results for all tested egg samples. Of the remaining 14 brooders, those (6) that were 1-step PCR positive after spawning gave $89 \%$ 2-step positive egg samples, while those that were only 2 -step PCR positive after spawning gave only $31 \%$ (Table 2, Fig. 2). All of the

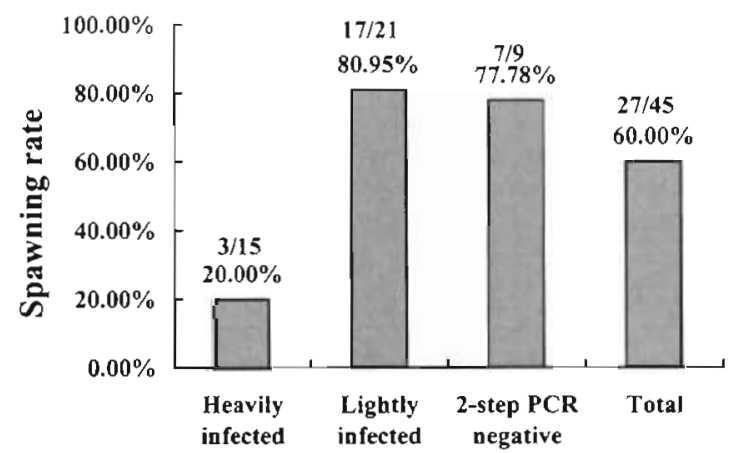

Fig. 1. Penaeus monodon. Negative impact of WSSV infection on spawning 


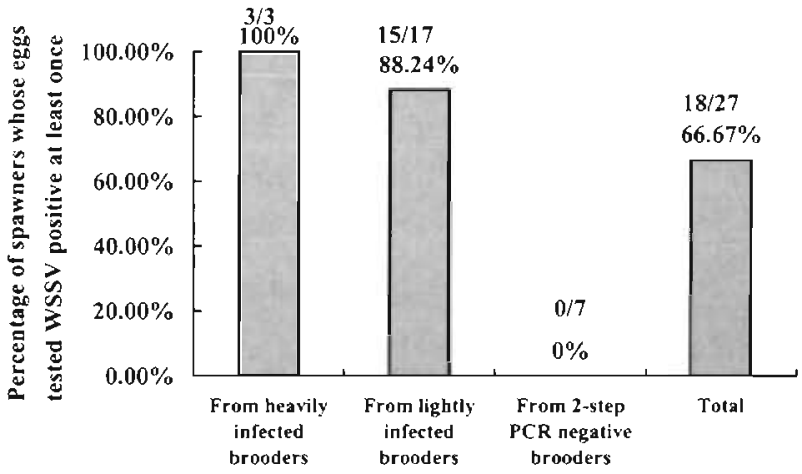

Fig. 2. Penaeus monodon. Influence of brooder infection on egg infection rate

tested eggs from the 2-step PCR negative brooders were 2-step PCR negative (Table 2, Fig. 2).

\section{DISCUSSION}

The inconsistency of 2-step PCR results from reexamination of stored DNA samples (Table 1) supports the hypothesis that equivocal PCR tests from offspring of 16 brooders in our earlier study (Lo et al. 1997) resulted from detection sensitivity limits. Similar results were obtained in a continuation study on the offspring of 1 brooder from the earlier study (Tsai et al. 1999). We therefore conclude that these samples had borderline concentrations of WSSV DNA and thus yielded different results with different sub-samples.

This sensitivity limit raises doubts as to the reliability of 2-step PCR for screening newly captured brooders, especially with respect to false negatives. Although the 2-step PCR has been shown to detect on the order of 20 copies of target plasmid in a PCR reaction mixture (Lo $\&$ Kou 1998), this may translate to a requirement for up to 1000 times more targets per gram of originally extracted tissue, depending on the amount and concentration of sample extract actually added to the PCR reaction vial. In addition, there is probably variation in numbers of viral particles in different pleopods from a single shrimp specimen. Because of these variables, it is likely that replicate PCR reactions from some lightly infected brooders would give inconsistent results such as those in Table 2 or false-negative results such as some of the pre-spawning results in Table 3 . On the other hand, the post-spawning results (Table 3) were completely consistent. The dramatic difference between the pre-and post-spawning results supports our earlier finding that various kinds of stress - including spawning stress - can trigger replication of WSSV (Lo et al. 1997). Within a few hours only, spawning stress brought virus quantities to levels easily and reliably detected by 2-step PCR.
The value of a diagnostic test can be judged by its repeatability, which is an indication of reliability (Thrusfield 1995). For tests with a dichotomous outcome, such as the PCR tests used here, the repeatability can be determined by assessing the agreement between results when a test is repeated 2 or more times. If a test is conducted 3 or more times, Cochran's Q-test can be used.

For the data in Table 3, the Cochran's Q-test was calculated for the replicates before and after spawning. Cochran's $Q$-test is calculated as:

$$
Q=\frac{(k-1)\left[k \sum G^{2}-\left(\sum G\right)^{2}\right]}{k \sum L-\sum L^{2}}
$$

where $k=$ number of replicates, $G=$ total number of positive results in each replicate, and $L=$ total number of positive results in each animal. Thus, for the PCR data before spawning, $Q=4 \mid(5 \times 1019)-5041] /[(5 \times 71)$ $-307]=216 / 48=4.5$. For the data after spawning, $Q=$ $4[(5 \times 2205)-11025] /[(5 \times 105)-525]=0$.

The difference in the values of $Q$ before and after spawning can be clearly seen. Referring to tables of $\chi^{2}$ for 4 degrees of freedom the $Q$-statistic before spawning gives a value which indicates a confidence level of around $50 \%\left(\chi^{2}=4.352\right)$, demonstrating poor repeatability of the test in pre-spawning broodstock, whereas the 0 value for replicates after spawning indicates perfect repeatability after spawning.

It is possible to solve the problem of pre-spawning, false-negative WSSV tests for brooders by increasing the number of replicate PCR tests carried out for each specimen. Reference to Table 1 shows that 3 replicates detected all of the positive samples that were eventually detected in 5 replicates, but in Table 3 some specimens required 5 replications. This is not a practical alternative due to the cost in time and money, so we propose that it would be more practical to screen brooders after spawning. At that time, it appears unlikely that borderline WSSV infections are obtained, and this should markedly decrease the probability of obtaining false-negative test results. Testing after spawning also has the added advantage of avoiding testing stress before spawning. This strategy may be appropriate only when production throughput is relatively low or for shrimp species like Penaeus monodon where egg production per spawn is high and brooders and their offspring can be individually reared. For example, production efficiency constraints necessitate pooling of $P$. vannamei brooders and eggs. In this case individual broodstock holding, spawning and offspring rearing would not be practical, especially in high throughput hatcheries.

Although no 1-step WSSV PCR positive brooders in our previous study spawned successfully (Lo et al. 1997), $3(20 \%$ ) did here (Fig. 1). Nonetheless, these 
3 brooders almost died after spawning. One (no. 9819S27) was even too weak to properly suspend its eggs and so they did not subsequently hatch into nauplii. In addition, $100 \%$ of the egg samples were 1 -step PCR positive for WSSV. Obviously, such brooders should be discarded before spawning.

We have already shown that successful harvests cannot be expected from ponds stocked with postlarvae derived from WSSV-infected eggs (Lo et al. 1998). Although the spawning rates of lightly infected brooders and the 2-step PCR negative brooders were similar ( 81 and $78 \%$, respectively), the lightly infected brooders gave $88 \%$ WSSV-infected egg batches, some with intense infections or high prevalence (Table 2). Unfortunately, some of the lightly infected brooders tested 2step PCR negative before spawning. Thus, the data argue strongly that brooders should be screened after spawning and that egg batches from 1 -step WSSV PCR positive spawners should be discarded. Under ideal circumstances, eggs from 2-step WSSV PCR positive brooders should also be discarded. However, under circumstances of low postlarvae availability, it may be possible with appropriate monitoring to utilize the eggs from lightly infected brooders since (1) some $(2=$ $20 \%$ ) gave egg samples that were 2 -step PCR negative, (2) none gave egg samples that were 1-step PCR positive and (3) the prevalence of 2 -step WSSV PCR positive samples was only $30 \%$. It may be possible to rear such eggs to become postlarvae that are 2-step PCR negative or at most 2-step PCR positive for WSSV. We have previously shown (Lo et al. 1998) that ponds stocked with 2-step PCR positive postlarvae can be brought through to successful harvest under low-stress cultivation conditions and with appropriate monitoring to reduce the risk of a WSSV outbreak.

Acknowledgements. This work was supported by the National Science Council under grant no. NSC 88-2317-B002-003. We thank Dr Liao, Director General, Taiwan Fisheries Research Institute (TFRI), for his constructive suggestions. We are indebted to Paul Barlow for his helpful criticism of the manuscript and to D. F. Fegan for help with Cochran's Q-test.

\section{LITERATURE CITED}

Cai S, Huang J, Wang C, Song X, Sun X, Yu J, Zhang Y, Yang $C$ (1995) Epidemiological studies on the explosive epidemic disease of prawn in 1993-1994. J Fish China 19 $112-117$

Chou HY, Huang CY, Wang CH, Chiang HC, Lo CF (1995) Pathogenicity of a baculovirus infection causing white spot syndrome in cultured penaeid shrimp in Taiwan. Dis Aquat Org 23:165-173

Editorial responsibility: Timothy Flegel,

Bangkok, Thailand
Inouye K, Miwa S, Oseko N, Nakano H, Kimura T (1994) Mass mortalities of cultured kuruma shrimp, Penaeus japonicus, in Japan in 1993: electron microscopic evidence of the causative virus. Fish Pathol 29:149-158 (in Japanese)

Lo CF, Kou GH (1998) Virus-associated white spot syndrome of shrimp in Taiwan: a review. Fish Pathol 33(4):365-371

Lo $\mathrm{CF}$, Leu JH, Ho CH, Chen $\mathrm{CH}$, Peng SE, Chen YT, Chou CM, Yeh PY, Huang $\mathrm{CJ}$, Chou HY, Wang $\mathrm{CH}$, Kou GH (1996a) Detection of baculovirus associated with white spot syndrome (WSBV) in penaeid shrimps using polymerase chain reaction. Dis Aquat Org 25:133-141

Lo CF, Ho CH, Peng SE, Chen CH, Hsu HC, Chiu YL, Chang CF, Liu KF, Su MS, Wang CH, Kou GH (1996b) White spot syndrome baculovirus (WSBV) detected in cultured and captured shrimp, crabs and other arthopods. Dis Aquat Org 27:215-225

Lo CF, Ho CH, Chen $\mathrm{CH}$, Liu KF, Chiu YL, Yeh PY, Peng SE, Hsu HC, Liu HC, Chang CF, Su MS, Wang CH, Kou GH (1997) Detection and tissue tropism of white spot syndrome baculovirus (WSBV) in captured brooders of Penaeus monodon with a special emphasis on reproductive organs. Dis Aquat Org 30:53-72

Lo CF, Chang YS, Cheng CT, Kou GH (1998) PCR monitoring of cultured shrimp for white spot syndrome virus (WSSV) infection in growout ponds. In: Flegel TW (ed) Advances in shrimp biotechnology. National Center for Genetic Engineering and Biotechnology, Bangkok, p 281-286

Momoyama $K$, Hiraoka $M$. Nakano $H$, Koube $H$ Inouye $K$, Oseka N (1994) Mass mortalities of cultured kuruma shrimp, Penaeus japonicus, in Japan in 1993: histopathological study. Fish Pathol 29:141-148 (in Japanese)

Nakano H, Koube H, Umezaea S, Momoyama K, Hiraoka M, Inouye K, Oseko N (1994) Mass mortalities of cultured kuruma shrimp, Penaeus japonicus, in Japan in 1993: epizootiological survey and infection trials. Fish Pathol 29 135-139 (in Japanese)

Peng SE, Lo CF, Ho CH, Chang CF, Kou GH (1998) Detection of white spot baculovirus (WSBV) in giant freshwater prawn, Macrobrachium rosenbergii, using polymerase chain reaction. Aquaculture 164:253-262

Takahashi Y, Itami T, Kondom M, Maeda M, Fujii R, Tomonaga S, Supamattaya K, Boonyaratpalin S (1994) Electron microscopic evidence of bacilliform virus infection in Kuruma shrimp (Penaeus japonicus). Fish Pathol 29: $121-125$

Thrusfield MV (1995) Veterinary epidemiology, 2nd edn. Blackwell Science Ltd, Oxford

Tsai MF, Kou GH, Liu HC, Liu KF, Chang CF, Peng SE, Hsu HC, Wang CH, Lo CF (1999) Long-term presence of white spot syndrome virus (WSSV) in a cultivated shrimp population without disease outbreaks. Dis Aquat Org 38 107-114

Wang $\mathrm{CH}_{\text {, Lo } \mathrm{CF}}$ Leu JH, Chou CM, Yeh PY, Chou HY, Tung MC, Chang CF. Su MS, Kou GH (1995) Purification and genomic analysis of baculovirus associated with white spot syndrome (WSBV) of Penaeus monodon. Dis Aquat Org 23:239-242

Wongteerasupaya C, Vickers JE, Sriurairatana S, Nash GL Akarajamorn A, Boonsaeng V, Panyim S, Tassanakajon A. Withyachumnarnkul B, Flegel TW (1995) A non-occluded, systemic baculovirus that occurs in cells of ectodermal and mesodermal origin and causes high mortality in the black tiger prawn Penaeus monodon. Dis Aquat Org 21:69-77

Submitted: January 25, 1999; Accepted: September 6, 1999 Proofs received from author(s): December 7, 1999 